\title{
Dayah \& Moderasi Dakwah di Aceh (Suatu Kajian Terhadap Dakwah di Era Digital)
}

\section{Dayah \& Moderation of Dakwah in Aceh (a Study of Dakwah in the Digital Era)}

\author{
Safriadi \\ Institut Agama Islam Negeri Lhokseumawe \\ Email: yadi_nsm@yahoo.co.id \\ Artikel diterima 26 Maret 2020, diseleksi 26 Mei 2020, \\ dan disetujui 05 Juli 2020
}

Abstrak: Penelitian ini berkesimpulan bahwa dayah di Aceh merupakan salah satu lembaga dakwah yang tertua nusantara bahkan di Asia Tenggara yang memiliki andil besar dalam menyebarkan dakwah di Nusantara. Keberhasilan dakwah yang dilakukan oleh dayah-dayah di Aceh dikarenakan bentuk dan gaya dakwahnya yang cenderung moderat. Moderat yang dimaksudkan disini adalah dalam penyampaian dakwahnya selalu ditonjolkan ketinggian akhlak dan adab sopan santun, sehingga masyarakat memiliki kesan positif dalam setiap dakwah yang disampaikan, senantiasa menyiapkan bahan ceramah dari isi kitab kuning yang dipelajari di dayah/pesantren dan sudah di tashiholeh pimpinan pesantren. Dalam hal penyampaian dakwah di era digital ini, dayah di Aceh sudah mulai menggunakan kemajuan teknologi digital seperti youtube, facebook dan lain-lain, meskipun masih sedikit dayahdayah di Aceh yang menggunakan media dalam penyampaian dakwahnya.

Kata Kunci: Dayah, Moderat, Dakwah, Era Digital.

Abstract This study concludes that dayah in Aceh was one of the oldest preaching archipelago institutions even in Southeast Asia which had big contribution in spreading da'wah in the archipelago. The success of da'wah by dayah-dayah in 
Aceh was due to the moderate da'wah form and style. Moderate here is in the delivery of da'wah always highlighted in morality and manners, so that the community has a positive impression in each preaching that is conveyed, always preparing lecture material from the contents of the Islamic book learned at the dayah / pesantren and already received by the pesantren leaders. In terms of the da'wah delivery in this digital era, dayah in Aceh have begun to use advances in digital technology such as youtube, facebook and others, even though there are still few dayah in Aceh who use the media in delivering their da'wah.

Keywords: Dayah, Moderat, Dakwah, Digital Age.

\section{A. Pendahuluan}

Dayah adalah sebuah lembaga pendidikan dan dakwah Islam telah dianggap sebagai pelopor tumbuh dan berkembang suburnya institusiinstitusi Pendidikan\& dakwah Islam di nusantara. Artinya cikal bakal pengembangan dakwah di nusantara di awali dari Aceh lewat lembaga pendidikan Islamnya yaitu dayah/pesantren ${ }^{1}$ yang mendidik kader-kader ulama yang mampu menjalankan dan meneruskan misi-misi kenabian. ${ }^{2}$

Dayah dinilai lembaga Islam yang unik, yang keunikannya juga telah membuat hampir setiap orang mengenalnya. Dilihat dari sisi kesejarahannya dayah telah berdiri lebih dari 500 tahun yang lalu serta merambah di seluruh kepulauan nusantara. Bahkan sebelum datangnya bangsa Eropa, institusi pendidikan Islam ini merupakan media dakwah signifikan yang ditempuh oleh para kiai, teungku, abuya, ustadzustadz serta orang-orang sufi.Kepercayaan diri dan kebanggaan atas ketradisionalitasannya justru merupakan faktor yang membuat dayah semakin survive, bahkan sebagai alternatif dalam glamouritas dan hegemoni modernisme.Dayah yang karakteristiknya sangat humanis dan moderat, meniscayakan posisinya acaptable dengan kemajuan teknologi.

Di Aceh khususnya paradigma dayah "tradisional" 3 masih dominan mewarnai dunia dayah di Aceh secara general dibandingkan dengan 
dayah terpadu/ modern, ${ }^{4}$ dayah tradisional lebih berkenaan dengan sistem pendidikan yang cenderung menggiring seseorang berpikir secara khusus dalam ajaran-ajaran Islam, tanpa melirik kepada kemajuan zaman. Secara umum,dayah/pesantren di Aceh itu dapat dibagi kepada dua macam tipe. Pertama, pondok pesantren yang benar-benar masih bersifat tradisional (purely traditional) yaitu yang tidak mau mengadopsi teori-teori pendidikan modern. Kedua, pondok pesantren modern, yaitu yang mau mengadopsi bentuk-bentuk sekolah, sehingga pendidikan terkombinasi dengan kurikulum sekolah-sekolah umum. Seiring dengan dominasi tradisionalnya pesantren di Aceh, maka media dakwah yang digunakan juga masih dominan memakai media yang lama seperti di mesjid dan musalla dengan sistem ceramah. Kecuali beberapa dayah/ pesantren yang sudah mengadopsi sistem modern dan digital dalam menyampaikan dakwahnya, seperti pesantren MUDI MESRA Samalanga dan Raudhatul Maarif Cot Trueng. Walaupun kedua pesantren ini masih bercorak tradisional, namun dalam pelaksanaan dakwahnya sudah sangat moderasi. Artinya bagaimana teknik dan metode dayah-dayah di Aceh dalam membangun strategi dakwah agar dapat sejalan dengan karakter manusia moderen yang global.

Sejalan dengan perkembangan zaman, dakwah seyogianya harus mengikuti tata cara, model dan gaya yang berlaku pada zaman tersebut.Pada era sekarang yaitu era digital, teknologi dan informasi, memungkinkan seorang da'i untuk berimprovisasi dengan beberapa metode baru, agar materi ceramahnya tetap menarik untuk disimak dan tidak ketinggalan zaman. Mengingat tantangan dakwah diera digital, teknologi dan informasi, khususnya media memang tidak bisa dilepaskan dari wahana hiburan atau nuansa baru. Dampaknya, orientasi dakwah yang diperankan para da'i, juga semakin berkembang, bahkan cenderung menjadi bias.

Dilihat dari enigma-enigma diatas, maka penelitian ini mencoba untuk melihat sisi moderasi dakwah dari lembaga-lembaga pesantren di Aceh yang notabenenya cendrung tradisionalis di era digitalisasi. 


\section{B. Pembahasan}

\section{Ontologi Dakwah}

Dakwah ditilik secara bahasa berasal dari kata"دعا- يدعو- دعوة", yang berarti memanggil, mengajak, dan menyeru. Di dalam al-Quran, kata dakwahyang akarkatanya terdiri dari dal, ain, dan wawu memilikibeberapa ragambentuk dan maknanya. Ada 198 kali al-Quran menyebutkan kata dakwah danramifikasinya yang tersebar dalam 55 surat (176 ayat). Jumlah kata dakwahdan ramifikasinya disebutkan dalam al-Quran lebih banyak dari jumlah ayatyang memuatnya. Ada 18 ayat yang muatan kata dakwah di dalamnya lebihdari satu kata, dan ada dua ayat yang masingmasing memuat sebuah katadakwah. Akan tetapi, kedua kata tersebut masing-masing memiliki dua artisekaligus. Sementara itu, makna kata dakwah dan ramifikasinya ada yangberhubungan secara vertikal (doa dan menyembah) dan ada yang berhubungan secara horizontal (seruan, panggilan, ajakan, perminataan, harapan,undangan, dan lain-lain).

Islam adalah agama dakwah yaitu agama yang mengajak dan memerintahkan umatnya untuk selalu menyebarkan dan menyiarkan ajaran Islam kepada seluruh umat manusia ${ }^{5}$. Keharusan tetap berlangsungnya dakwah Islamiyah di tengah-tengah masyarakat itu sendiri, merupakan realisasi dari salah satu fungsi hidup setiap manusia muslim, yaitu sebagai penerus risalah Nabi Muhammad Saw, untuk menyeru dan mengajak manusia menuju jalan Allah, jalan keselamatan dunia akhirat. Disamping fungsi hidup sebagai khalifah di muka bumi ini. ${ }^{6}$

Keharusan tetap berlangsungnya dakwah Islamiyah yang merupakan tugas sebagai manusia Muslim sudah tercantum dalam kitab suci alQur'an, surat al- Imran ayat 104:

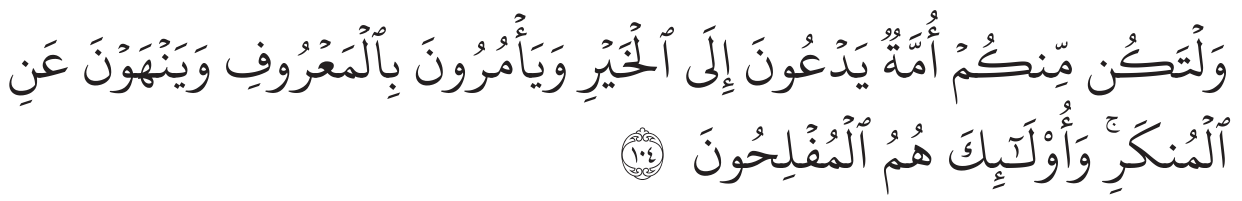


Artinya: Dan hendaklah ada diantara kamu segolongan umat yang menyeru kepada kebajikan, menyuruh kepada yang ma'ruf dan mencegah dari yang mungkar;merekalah orang-orang yang beruntung.(QS. Ali Imran, 104)

Dakwah dapat diartikan dengan ajakan untuk mengenal sesuatu ajaran atau doktrin suatu agama tertentu, maka kata dakwah dapat dipakai oleh agama apa saja. Adapun yang dimaksud secara spesifik oleh penulis disini adalah penyiaran, propaganda dan seruan untuk mempelajari dan mengamalkan ajaran agama. ${ }^{7}$

Dakwah juga berarti suatu proses upaya mengubah suatu situasi kepada situasi lain yang lebih baik sesuai ajaran Islam atau proses mengajak manusia kejalan Allah Subhanahu wa Ta'ala, yaitu agama Islam.

Menurut Munzir Saputra dakwah berarti pekerjaaan atau ucapan untuk mempengaruhi manusia mengikuti Islam ${ }^{8}$. Adapun Bakhail Khauli mendefinisikan dakwah dengan suatu proses menghidupkan peraturan-peraturan Islam dengan maksud memindahkan umat dari suatu keadaan kepada keadaan yang lain. ${ }^{9}$

Syekh Ali Mahfuzh mengartikan dakwah dengan mengajak manusia untuk mengikuti kebaikan dan petunjuk, menyeru mereka berbuat baik dan melarang mereka berbuat jahat agar mereka mendapatkan kebahagiaan di dunia dan akhirat. ${ }^{10}$

Dari uraian di atas, dapat dipahami bahwa dakwah memiliki dimensi yang luas. Setidaknya, ada empat aktivitas dakwah, yaitu:

1. Mengingatkan orang-orang akan nilai-nilai kebenaran dan keadilan dengan lisan

2. Mengkomunikasikan prinsip-prinsip Islam melalui karya tulisnya,

3. Memberi contoh keteladanan akan perilaku/akhlak yang baik,

4. Bertindak tegas dengan kemampuan fisik, harta, dan jiwanya dalam menegakan prinsip-prinsip Ilahi. ${ }^{11}$ 
Adapun tujuan dakwah Islam meliputi:

a. Agar setiap masyarakat atau penerima dakwah hendaknya mengetahui, memahami, dan meyakini ajaran Islam yang sebenarnya yaitu meyakini bahwa agama Islam satu-satunya agama yang benar di sisi Allah Swt.

b. Agar dapat m,engamalkan ajaran Islam sesuai dengan apa yang di contohkan Allah dan Rasul-Nya.

c. Agar dapat berakhlak Islam sesuai dengan apa yang dicontohkan Rasul

d. Bila masyarakat atau penerima dakwah itu telah mengetahui, memahami, meyakini, mengamalkan, dan berakhlak mulia, maka diwajibkan untuk mendakwakan kepada orang lain.

Semua tujuan-tujuan di atas merupakan penunjang dari pada tujuan akhir. Dan tujuan akhir dakwah Islam adalah terwujudnya kebahagian hidup di dunia dan di akhirat.

\section{Dayah Sebagai Lembaga Dakwah di Aceh}

Aceh merupakan pintu gerbang awal bagi perkembangan ajaran Islam di nusantara. ${ }^{12}$ Islam begitu membumi di daerah ini setelah menampakkan keberadaannya di tengah-tengah masyarakat dengan menjadikan Islam sebagai agama rakyat dan sebagai agama resmi kerajaan yang berfungsi sebagai landasan dan azas pembinaan adat, budaya dan karakter masyarakat yang santun. Melalui bimbingan ajaran agama Islam secara komprehensif, masyarakat Aceh menjadi masyarakat madani yang jujur, adil, ikhlas dan berani menegakkan kebenaran dan menentang segala bentuk kebathilan dan kezaliman.

Eksistensi Islam di tengah-tengah komunitas masyarakat Aceh telah memberikan warna tersendiri dalam sejarah perkembangan sosiokultural bagi masyarakat yang berada di propinsi ujung utara pulau Sumatera. Secara historis, Aceh terdiri dari berbagai negara bagian 
kecil seperti Peureulak, Samudera Pasee, Pidie dan Daya. Karenanya awal abad XVI, Aceh adalah satu negara yang besar setelah seluruh kerajaan bersatu di bawah bendera kekuasaan Aceh Darussalam (cikal bakal nama propinsi Aceh pasca era reformasi). Namun ketika Aceh diperintah oleh empat Ratu dan sultan-sultan berikutnya, kerajaan Aceh mengalami kemunduran yang pada akhirnya saat Indonesia merdeka, para pemimpin Aceh memutuskan untuk bergabung dengan republik Indonesia. $^{13}$

Dayah merupakan salah satu lembaga dakwah yang paling utama di Aceh. Dayah adalah sebutan orang Aceh terhadap zawiyah yang berasal dari bahasa Arab. Secara literal bermakna sebuah sudut yang digunakan Nabi untuk mengajar cara berdakwah pada masa awal keislaman di Madinah. Sesudah para sahabat Nabi belajar di sudut Mesjid Nabawi, mereka menyebar ke seluruh jazirah Arab untuk mneyebarkan ilmu pengetahuan yang Nabi berikan yang disebut dengan nama lain "berdakwah". ${ }^{14}$ Selanjutnya kata "zawiyah" berobah menjadi dayah

Keberadaan lembaga dayah bagi pengembangan dakwah di Aceh sangatlah urgen, dan kebermaknaan kehadirannya sangat dibutuhkan dalam membentuk umat yang berpengetahuan, jujur, cerdas, rajin dan tekun beribadah yang kesemuanya itu sarat dengan nilai. Sejarah membuktikan bahwa Sultan pertama di kerajaan Peureulak (840 M), meminta beberapa ulama dari Arabia, Gujarat dan Persia untuk mengajar di lembaga ini. Untuk itu sultan membangun satu dayah yang diberi nama "Dayah Cot Kala" yang dipimpin oleh Teungku Muhammad Amin, belakangan dikenal dengan sebutan Teungku Chik Cot Kala. Lembaga ini merupakan lembaga pendidikan tinggi Islam pertama di kepulauan Nusantara. ${ }^{15}$

Pada masa kesultanan Aceh, dayah menawarkan tiga tingkatan pengajaran, yakni rangkang (junior), balee (senior), dan dayah manyang (universitas). Di beberapa Dayah hanya terdapat rangkang dan balee, sedangkan di tempat lain hanya ditemui tingkat Dayah manyang saja. 
Meskipun demikian di tempat tertentu juga terdapat tiga tingkatan sekaligus, mulai junior sampai universitas. Sebelum murid belajar di dayah, mereka harus sudah mampu membaca Alqur'an yang mereka pelajari di rumah atau di meunasah dari seorang Teungku. Kepergian untuk menuntut ilmu agama di dayah sering disebut dengan meudagang. Metode mengajar di dayahpada dasarnya dengan meudrah ${ }^{16}$ dan metode hafalan. Pada kelas yang lebih tinggi, metode diskusi dan debat (meudeubat) sangat dianjurkan dalam segala aktifitas proses belajar mengajar, dan ruang kelas hampir merupakan sebuah ruang seminar. Para Teungku biasanya berfungsi sebagai moderator, yang kadang-kadang juga berperan sebagai pengambil keputusan. ${ }^{17}$

Santri (aneuk dayah) biasanya terdiri dari dua kelompok, yaitu santri kalong dan santri mukim/meudagang. Santri kalong merupakan bagian aneuk dayah yang tidak menetap dalam pondok, tetap pulang ke rumah masing-masing setelah belajar. Mereka biasanya berasal dari daerah sekitar dayah tersebut. Sementara santri mukim /meudagang adalah putra dan putri yang tinggal menetap dalam dayah dan biasanya berasal dari daerah jauh. ${ }^{18}$

Pendidikan dayah terkesan sangat monoton dalam penyusunan kurikulum yang masih berorientasi kepada sistem lama. Artinya kitab yang diajarkan adalah kitab-kitab abad pertengahan. Secara keseluruhan di bidang kurikulum ternyata tidak ada perubahan dan perkembangan, yang ada hanyalah pengulangan. Hal ini disebabkan pengaruh dari pendahulu yang begitu kuat sehingga tidak ada tokoh dayah yang berani untuk mengembangkan kurikulum yang representatif.

Sistem pendidikan yang dikembangkan di dayah tidak berbeda dengan apa yang dikembang di pesantren-pesantren di Jawa atau surausurau di Sumatera Barat, yakni bisa ditinjau dari berbagai segi, yaitu:

1. Ditinjau dari segi materi pelajarannya, yang diajarkan adalah mata pelajaran agama semata-mata yang bertitik tolak kepada kitab-kitab klasik (kitab kuning). Pada umumnya, pelajaran 
dimulai dengan kitab-kitab yang sederhana (kitab jawoe/kitab Arab Melayu) kemudian dilanjutkan dengan kitab-kitab yang lebih mendalam, tingkatan suatu dayah dapat diketahui dari jenis kitabkitab yang diajarkan. ${ }^{19}$ Ada delapan macam bidang pengetahuan dalam kitab-kitab Islam klasik yang di ajarkan di Dayah, yakni 1) Nahwu dan saraf (morfologi), 2) figh, 3) Ushul figh, 4) Hadist, 5) Tafsir, 6) Tauhid, 7) tasawuf dan etika, dan 8) cabang-cabang lain seperti Tarikh dan Balaghah. ${ }^{20}$ Tinggi rendahnya ilmu seseorang diukur dari kitab yang dipelajarinya.

2. Ditinjau dari segi metodenya adalah hafalan, meudrah dan muedeubat. Dalam tradisi pesantren di Jawa sering disebut sorogan dan wetonan.

3. Ditinjau dari segi sistem pembelajaran adalah non-klasikal. Yakni santri (aneuk dayah) tidak dibagi berdasarkan tingkatan kelas, tetapi berdasarkan kitab yang dipelajarinya. ${ }^{21}$

Kebiasaan orang Aceh, belajar di dayah, atau sering disebut meudagang, biasanya membutuhkan waktu yang tak terbatas. Artinya seorang murid datang dan meninggalkan dayahketika ia merasa sudah cukup ilmunya atau faktor-faktor yang kain. Beberapa aneuk dayah (santri) belajar di beberapa dayah, berpindah dari satu dayah ke dayah lainnya, setelah belajar beberapa tahun. Jumlah tahun yang dihabiskan oleh seorang murid tergantung pada ketekunannya atau pengakuan guru bahwa murid itu telah selesai dalam studinya. Kadang-kadang murid tersebut ingin melanjutkan studinya di dayahsampai ia sanggup mendirikan dayahnya sendiri. Dalam kaitan ini, tidak ada penghargaan secara diploma. Karena itu, setelah belajar dan mendapat pengakuan dari teungku chik (pimpinan dayah) mereka terjun ke dunia masyarakat dan bekerja sebagai Teungku di meunasah-meunasah, menjadi da'i atau imam-imam di mesjid-mesjid. ${ }^{22}$ 


\section{Moderasi Dakwah di Dayah-dayah di Aceh}

Setiap muslim berkewajiban untuk menyampaikan pesan pesan Islam yang terkandung dalam al-Quran. Penyampaian pesan ini disebut dengan "dakwah". Dakwah Islam sering kali menghadapi banyak tantangan, reaksi negatif bahkan tidak jarang cercaan dan perlawanan. Konteks masyarakat yang sangat majemuk, dengan berbagai perbedaan ras, suku, bahasa dan lainnya, sebegaimana yang ada di nusantara, ${ }^{23}$ kadang kala menjadi salah satu pemicu terjadinya berbagai reaksi negatif tersebut.

Untuk menjawab tantangan global perkembangan teknologi dan komunikasi, gerakan dakwah mesti disuguhkan dalam metode dan strategi yang tepat agar dapat berjalan seiring dengan perkembangan dunia global yang sangat dinamis. Dalam konteks ini, moderasi gerakan dakwah Islam menjadi satu keniscayaan agar syariat Islam tetap tersuguhkan kepada masyarakat dalam formulasi yang indah dan sejuk. Karena Islam sebagai satu paket tuntunan sudah sempurna dan sebagai syariat ilahi terakhir, tentunya dapat diimplementasikan selaras dengan perkembangan zaman.

Moderasi Dakwah dalam bahasa Arab disebut dengan al-Wasathiyyah al-dakwatiyah. Al-Qaradawi menyebut beberapa kosakata yang serupa makna dengannya termasuk kata Tawazun, I'tidal, Ta'adul dan Istiqamah. Sementara dalam bahasa inggris sebagai Mission Moderation. Moderasi Dakwah adalah sebuah pandangan atau sikap yang selalu berusaha mengambil posisi tengah dari dua sikap yang berseberangan dan berlebihan sehingga salah satu dari kedua sikap yang dimaksud tidakmendominasi dalam pikiran dan sikap seseorang dalam rangka menyebarkan dakwah.

Moderasi dakwah diperlukan karena mengingat Islam adalah agama pemersatu umat manusia dengan berbagai perbedaan ras, suku, bahasa dan lainnya. Islam mengedepankan perdamaian, keamanan dan stabilitas sosial untuk mewujudkan ketenteraman dan kesejahteraan umat. Islam juga melampui persaudaraan sesama muslim, dengan menghormati agama lain dan bangsa-bangsa lain. 
Dayah di Aceh pada umumnya dalam penyajian materi dakwahdiiringi dengan interaksi yang interaktif dengan masyarakat, sehingga apapun yang disampaikan oleh para da'i dayah kepada para sasaran dakwah (audien) yang terdiri dari berbagai lapisan masyarakat dengan sistim dan metode ceramah akan lebih efektif dan berhasil. Ceramah-ceramah yang disampaikan oleh para tengku dayah kepada masyarakat berupa materi-materi yang ada hubungannya dalam kehidupan sehari-hari.

Moderasi dakwah juga berkaitan dengan keahlian dan profesionalisme dai/tengku. Dimana profesionalisme tidak saja diukur dari segi kemampuan mengolah kata dan bahasa, melainkan juga didukung oleh cara penyampaian pesan, metodologi dakwah dan mempunyai penampilan yang menyakinkan. Dalam melaksanakan dakwah biasanya para da'i/tengku langsung terjun kedalam kehidupan masyarakat dan berbaur dengan masyarakat luas dan mengajak untuk selalu dalam taat kepada Allah swt, konsep dakwah para da'i dalam berdakwah kepada masyarakat umum sifatnya lebih terbuka, biasanya dakwah diselenggarakan pada malam hari dengan moment-moment memperingati hari-hari besar agama Islam, seperti pada perayaan maulid Nabi Muhammad Saw, Isra' Mi'raj, ceramah Ramadhan, Khutbah dua hari Raya yaitu hari Raya Idul fitri dan Idul Adha. Tempat pelaksanaan dakwah biasanya bertempat di surau atau langgar, mesjid dan balai-balai pengajian, namun kadang-kadang ada juga dilapangan terbuka seperti di tanah lapang.

Moderasi dakwah juga diukur dari keterlibatan masyarakat dalam pelaksanaan dakwah, dalam hal ini melakukan kerjasama antara pengurus desa dengan dayah, dan oleh pengurus dayah biasanya mengutuskan para da' inya untuk berpartisipasi langsung dalam kegiatan dakwah tersebut. Untuk merealisasi tugas dakwah tersebut para da $i$ dayah selalu memamfaatkan waktu yang senggang untuk membawa misi dakwahnya ditengah-tengah masyarakat yakni mengajarkan amar makruf nahi mungkar, dan sikap tasamuh antara sesama. 
Para da`i/tengku daridayah menerapkan sikap yang sangat hatihati dalam menyebarkan dakwah. Kehati-hatian ini dapat diukur dari proses seorang da'i dianggap mapan dan bisa diterjunkan ke dalam masyarakat.Langkah pertama yang ditempuhnya adalah dengan belajar berpidato (Muhadharah) ${ }^{24}$ pada setiap malam jum'at, dengan berbagai materi pembahasan menurut profesinya masing-masing. Setelah selesai belajar di kabilah masing-masing, para da'i junior tersebut di undang ke kabilah lain dalam lingkungan dayah untuk memberikan ceramah puncak di setiap kabilah.

Selanjutnya setelah ilmu tentang dakwah dan retorika mereka kuasai dari belajar dalam acara muhadharah maka, para tengkudisiapkan untuk bisa langsung terjun ke dalam masyarakat luas untuk mengemban misi dakwah. Pada prinsipnya setiap pribadi santri dayah telah terpatri rasa kewajiban untuk menyampaikan dakwah kepada masyarakat luas yang menyangkut dengan kemaslahatan umat. Untuk tercapainya tujuan tersebut diatas mereka para santri menempuh tiga cara, antara lain:

a. Ibadah sebagai landasan taqwa.

b. Berdakwah untuk mengembangkan ilmu dan amal

c. Mewujudkan kegiatan masyarakat yang islami dalam kehidupan sehari-hari.

Dengan dilandasi tiga pedoman dan cara tersebut maka para santri akan siap untuk tampil sebagai penganyom ditengah-tengah kehidupan masyarakat menurut ilmu yang mareka miliki, dan disamping tiga landasan pokok yang disebutkan diatas, mereka juga dilandasi dengan beberapa unsur lainnya, diantaranya adalah:

a. Adanya misi para santri dayah dalam berdakwah untuk kepentingan agama.

b. Adanya unsur kepentingan masyarakat banyak

c. Adanya unsur kepentingan bangsa dan Negara. 
Dalam misi demi kepentingan agama para da'i/tengku yang pada dasarnya santri biasanya dalam setiap melaksanakan dakwah tanpa mengharapkan pamrih sedikitpun walaupun itu hanya sekedar uang transport, karena mengabdi terhadap agama merupakan kewajiban bagi setiap pribadi muslim. Setiap umat Islam yang telah a'qil baliq wajib melaksanakan tugas dakwah menurut daya dan kemampuannya masing-masing, yaitu menyuruh kepada kebaikandan melarang berbuat mungkar, dan mengabdi kepada agama untuk meninggikan kalimat Allah Swt menjadi kewajiban manusia untuk mempertahankan agama Allah Swt dalam situasi dan kondisi yang bagaimanapun juga, baik itu harus berkorban dengan harta maupun dengan nyawa sekalipun sebagaimana yang dipraktekkan oleh para ulama-ulama yang telah gugur dalam mempertahankan agama Allah, baik dimasa permualaan Islam seperti yang telah dipraktekkan oleh para sahabat-sahabat Nabi maupun di zaman yang modern ini.

Dayah di Aceh dalam kurun waktu beberapa tahun terakhir ini, telah mengalami banyak perobahan khususnya model dakwah yang disampaikan para kiai/ tengku/da'i/ustad. Artinya orientasi dakwah yang dijalankan sudah mulai bergeser kepada menggunakan fasilitas internet, baik itu melalui fasilitas youtube, instagram, facebook, twitter dan lain-lain.Karena kegiatan dakwah akan dapat berjalan efektif dan efesien harus menggunakan cara-cara yang strategis, terukur, efektif dan efesien. Salah satu aspek yang bisa ditinjau adalah dari segi sarana dan prasarana dalam hal ini adalah media dakwah, karena dakwah merupakan kegiatan yang bersifat universal yang menjangkau semua segi kehidupan manusia, maka dalam penyampaiannya pun harus dapat menyentuh semua lapisan atau tingkatan baik dari sudut budaya, sosial, ekonomi, pendidikan dan kemajuan teknologi lainnya.

Penguasaan teknik komunikasi oleh pesantren adalah bagian terpenting dalam mengemban amanat dakwah. Oleh sebab itu, memanfaatkan teknologi sebagai sarana dakwah adalah sebuah kebutuhan yang sangat urgen dan mendesak yang mesti diambil oleh 
dayah sebagai lembaga dayah di Aceh. Pemanfaatan youtube dalam menyiarkan dakwah, facebook dengan akun-akun dakwah adalah sebuah keniscayaan dan hal yang mutlak diperlukan. Walaupun dayah yang bergerak dan memanfaatkan sarana dan fasilitas ini di Aceh masih sedikit, namun keinginan ke arah yang demikian sudah muncul dan akan senantiasa mengalami perkembangan.

Penggunaan media internet dalam berdakwah oleh pesantren/dayah merupakan sebuah kesempatan dan tantangan untuk mengembangkan dan memperluas cakrawala dakwah Islamiyah. Kesempatan yang dimaksud ialah bagaimana orang-orang yang peduli terhadap kemampuan dakwah maupun memanfaatkan media internet tersebut sebagai sarana dan media dakwah untuk menunjang proses dakwah Islamiyah. Sementara mewujudkannya mulai dari tenaga, pikiran dan sumber daya manusia yang mengerti akan dakwah dan internet. Umat Muslim harus mampu menguasai dan memanfaatkan sebesar-besarnya perkembangan teknologi informasi, dari sisi dakwah, kekuatan internet sangat potensial untuk dimanfaatkan.

\section{Penutup}

Dayah/pesantren di Acehmerupakan lembaga yang bergerak dalam bidang pendidikan Islam, Syiar dan dakwahIslam.Dalam menghadapi era yang serba digital seperti saat ini, maka Dayah harus memiliki fungsi sebagai berikut :

1. Sebagai wadah gerakan dakwah yang moderat,

2. Menjadi ruang alternatif bagi masyarakat luas untuk belajar tentang hakikat Islam.

Kemoderatan dakwah yang dipraktekkan di dayah di Aceh dapat didentifikasikan dengan ketinggian sikap dan akhlakdalam penyampaian dakwah, setiap materi dakwah yang hendak disampaikan diuji dan ditashihkan kepada Abu/Kiayi di dayah dan pesantren. Pengujian ini adalah sebagai bentuk kehati-hatian dalam memberikan dakwah dalam 
masyarakat. Dayah di Aceh juga mulai mengadopsi media digital seperti youtube, facebook, twitter, dan lain-lain dalam penyampaian syiar dakwahke dalam masyarakat. 


\section{Daftar Pustaka}

Amiruddin,M. Hasbi,Ulama Dayah, Pengawal Agama Masyarakat Aceh (Lhokseumawe: Nadiya Foundation, 2003)

Amsyari,Fuad, Dakwah dalam Berbagai Aspek, (Bandung:Rosda Karya 1993)

Darussalam, Ghazali, Dinamika Ilmu Dakwah Islamiyah, (Jakarta:Nur Niaga,1996)

Dhofier,Zamakhsari,Tradisi Pesantren: Studi Tentang Pandangan hidup Kyai (Jakarta: LP3ES, 1985)

Dhuhri, Saifuddin, Dayah:Menapaki Jejak Pendidikan Warisan Endatu Aceh, (Aceh:Lhee Sagoe Press, 2014)

H. Halimi AR, Problematika Dakwah Masa Kini dan Pemecahannya, naskah makalah yang disampaikan dalam seminar pada tanggal 24 februari 2003

Hasanuddin, Hukum Dakwah, (Jakarta:Pedoman Ilmu Jaya, 1996)

Hasbullah, Sejarah Pendidikan Islam di Indonesia: Lintasan Sejarah Pertumbuhan dan Perkembangan (Jakarta: Raja Grafindo Persada, 1999),

https://dpd.acehprov.go.id/index.php/page/7/tipe-dayah.

Muhidin, Asep, Dakwah Dalam Perspektif Alqur'an, (Bandung: Pustaka Setia, 2002)

Saputra, Munzir, Meetode Dakwah, (Jakarta: Rahmat Semesta, 2003)

Shaleh, Abd. Rosyad, Managemen Dakwah Islam, (Jakarta:Bulan Bintang, 1987) 
Sufi, Rusdi,Pandangan dan Sikap Ulama di Daerah Istimewa Aceh (Jakarta: LIPI, 1987)

Sunanto, Musyrifah, Sejarah Peradaban Islam Indonesia (Jakarta: Raja Grafindo Persada, 2005) 


\section{Endnotes}

1. Yaitu dayah Cot Kala yang dikenal sebagai dayah/pesantren pertama di Nusantara bahkan di Asia Tenggara. Lihat selengkapnya Saifuddin Dhuhri, Dayah:Menapaki Jejak Pendidikan Warisan Endatu Aceh, (Aceh:Lhee Sagoe Press, 2014), h. 23

2. Salah satu misi kenabian adalah untuk menyempurnakan ahklak ummat manusia, sebagaimana tersebut dalam hadits:

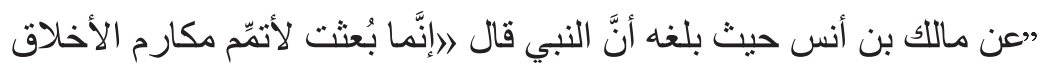

Sesungguhnya aku diutus ke bumi hanyalah untuk menyempurnakan kemuliaan akhlak".

3. Dayah/pesantren di Aceh, diklasifikasikan kepada beberapa model dan type. Ada type dayah tradisional/ salafiyah dan modern/terpadu. Selengkapnya baca di halaman https://dpd.acehprov.go.id/index.php/page/7/tipe-dayah.

4. Dilihat dari sistem pengajaran yang diterapkan, perbedaan antara dayah/ pesantren dapat digambarkan bahwa dayah tradisional hanya fokus pada pendalaman Ilmu Agama melallui kitab turats sedangkan pesantren modern sama dengan halnya sekolah asrama (boarding school) tapi menerapkan nilai- nilai Islam yang kuat, dan kebanyakan fokus kepada bahasa Asing (Inggris dan Arab umumnya)

5. Abd. Rosyad Shaleh, Managemen Dakwah Islam, (Jakarta:Bulan Bintang, 1987), h. 1

6. H. Halimi AR, Problematika Dakwah Masa Kini dan Pemecahannya, naskah makalah yang disampaikan dalam seminar pada tanggal 24 februari 2003. H. 1

7. Asep Muhidin, Dakwah Dalam Perspektif Alqur'an, (Bandung: Pustaka Setia, 2002), h. 1

8. Munzir Saputra, Meetode Dakwah, (Jakarta: Rahmat Semesta, 2003), h. 154

9. Hasanuddin, Hukum Dakwah, (Jakarta:Pedoman Ilmu Jaya, 1996), h. 35 
10. Ghazali Darussalam, Dinamika Ilmu Dakwah Islamiyah, (Jakarta:Nur Niaga,1996),h. 5

11. Fuad Amsyari,Dakwah dalam Berbagai Aspek, (Bandung:Rosda Karya 1993), h. 161

12. Sebuah realitas bahwa Islam hadir ke nusantara dilakukan secara damai tanpa pendudukan wilayah oleh kekuatan militer. Islam dalam batasan tertentu disebarkan oleh pedagang, kemudian dilanjutkan oleh para guru agama (da'i) dan pengembara sufi. Orang yang terlibat dalam kegiatan dakwah pertama itu tidak bertendensi apapun selain bertanggungjawab menunaikan kewajiban tanpa pamrih, sehingga nama mereka berlalu begitu saja, tanpa meninggalkan sejarah dan prasasti pribadi yang sengaja dibuat mereka untuk mengabadikan peran mereka. Ditambah lagi wilayah nusantara ini sangat luas dengan perbedaan kondisi dan situasi. Oleh karena itu, wajar kalau terjadi perbedaan pendapat tentang kapan, dari mana dan dimana pertama kali Islam datang ke nusantara. Musyrifah Sunanto, Sejarah Peradaban Islam Indonesia (Jakarta: Raja Grafindo Persada, 2005), h. 7-8.

13. M. Hasbi Amiruddin, Ulama Dayah, Pengawal Agama Masyarakat Aceh (Lhokseumawe: Nadiya Foundation, 2003), h. 1.

14. Saifuddin Dhuhri, Dayah...,h, 20-21

15. M. Hasbi Amiruddin, Ulama Dayah..., h. 36 - 37.

16. Meudrah adalah suatu metode dimana murid datang satu per satu kepada seorang teungku rangkang dengan kitabnya atau copy teks (kurah) yang sedang mereka pelajari, kemudian teungku membaca teks, memberikan komentar dan catatan dalam bacaannya tersebut, lalu meminta murid untuk membaca kembali teks yang telah ia bacakan.

17. Rusdi Sufi, Pandangan dan Sikap Ulama di Daerah Istimewa Aceh (Jakarta: LIPI, 1987), h. 29.

18. Zamakhsari Dhofier, Tradisi Pesantren: Studi Tentang Pandangan hidup Kyai (Jakarta: LP3ES, 1985), h. 52.

19. Hasbullah, Sejarah Pendidikan Islam di Indonesia: Lintasan Sejarah Pertumbuhan dan Perkembangan (Jakarta: Raja Grafindo Persada, 1999), h. 144.

20. Dhofier, Tradisi Pesantren..., h. 51. 
21. Daulay, Dinamika Pendidikan..., h. 128.

22. Mengajar di suatu meunasah dan menjadi imam shalat adalah pekerjaan suka rela. Dalam hal ini teungku tidak dibayar kecuali dari sedekah. penghasilan mereka sebagai guru tersebut didapatkan dari profesi sebagai pedagang atau petani; meski beberapa ulama yang memimpin dayah juga bekerja sebagai petani, tukang kayu, servis mekanik, dsb.

23. Ada lebih dari 300 kelompok etnik atau suku bangsa di Indonesia, atau tepatnya 1.340 suku bangsa menurut sensus BPS tahun 2010. Suku Jawa adalah kelompok suku terbesar di Indonesia dengan jumlah mencapai 41\% dari total populasi. Orang Jawa kebanyakan berkumpul di pulau Jawa, akan tetapi jutaan jiwa telah bertransmigrasi dan tersebar ke berbagai pulau di Nusantara, bahkan bermigrasi ke luar negeri seperti ke Malaysia dan Suriname. Suku Sunda, Suku Batak, dan Suku Madura adalah kelompok terbesar berikutnya di negara ini.

24. Banyak suku-suku terpencil, terutama di Kalimantan dan Papua, memiliki populasi kecil yang hanya beranggotakan ratusan orang. Sebagian besar bahasa daerah masuk dalam golongan rumpun bahasa Austronesia, meskipun demikian sejumlah besar suku di Papua tergolong dalam rumpun bahasa Papua atau Melanesia.

25. https://id.wikipedia.org/wiki/Suku_bangsa_di_Indonesia

26. ${ }^{24}$ kegiatan muhadharah itu dilaksanakan di bale (ruang belajar)masingmasing. Para santri setiap malam jum ’at mereka mengikuti kegiatan muhadharah di kabilah masing. 